\title{
BIOCHEMICAL RESPONSES AND GENETIC EXPRESSIONS OF SYNTHETIC COMMON CARP POPULATIONS EXPOSED TO HIGH-AMMONIA REARING ENVIRONMENT
}

\author{
Yogi Himawan ${ }^{* \#}$, Alimuddin*), Kukuh Nirmala**, Imron*), and Joni Haryadi*) \\ *) Research Institute for Fish Breeding \\ Jl. Raya No. 2, Sukamandi, Subang 41256 \\ * IPB University \\ Kampus IPB, JI. Raya Dramaga, Babakan, Kec. Dramaga, Kota Bogor, Jawa Barat 16680
}

(Received: September 10, 2019; Final revised: April 6, 2021; Accepted: April 7, 2021)

\begin{abstract}
Carp is one of the leading freshwater aquaculture commodities in Indonesia. Further improvement of carp strains by the Research Institute for Fish Breeding (RIFB), Sukamandi, Indonesia, has produced a synthetic F2 carp. The strain is assembled from different strains of carps and has shown better growth and health characteristics. Considering that high environmental ammonia (HEA) has affected most carp grow-out systems, this study aimed to determine the performance of the synthetic carp populations in a high ammonia rearing environment. The treatments were rearing media of the synthetic carp seed populations added with and without (control) $200 \mathrm{mg} / \mathrm{L} \mathrm{NH}{ }_{4} \mathrm{Cl}$ arranged in three replicates. A total of 30 fish seeds/ aquarium, weighed 10-15 g/fish, was used in the study. Dissolved oxygen levels were maintained above 2 $\mathrm{mg} / \mathrm{L}$ using aeration. This study shows that higher tolerant carp populations had red blood cells of 232.66 \pm 17.24 cell $\mathrm{s} / \mathrm{mL}$, indicating a direct effect of high ammonia on red blood cell count $(p<0.05)$. Cortisol levels of $80.90 \pm 6.35 \mathrm{ng} / \mathrm{mL}$ in resistant carp indicate significant differences $(p<0.05)$. The relative expressions of the HSP70 gene in the liver (Log10) ranged between 0.72 and 2.80. The values demonstrate that high ammonia-resistant synthetic carp have a higher relative expression ratio of the HSP70 gene than the less resistant group. This research concluded that the populations of synthetic F2 carp showed a degree of resistance against high-ammonia rearing conditions. When it is ready for aquaculture, this synthetic carp strain could be farmed in high density using intensive systems in HEA-affected artificial lakes and reservoir
\end{abstract}

\section{KEYWORDS: synthetic; high ammonia; red blood cell; cortisol; HSP70 gene}

\section{INTRODUCTION}

One of the factors that influence carp production capacity is the frequent occurrences of high ammonia in the carp farming environment (Kawasaki et al., 2016), especially in floating net cage (FNC) located in reservoirs and artificial lakes. The phenomena are triggered by seasonal nutrient turnover or cycling phenomena in water bodies due to weather changes. Sinha et al. (2012) state that increased ammonia content in freshwater bodies such as lakes and reservoirs has become a major problem in fisheries and aquaculture. The toxicity induced by high environmental ammonia (HEA) affects the performance and inhibits fish growth (Hegazi \& Hasanein, 2010). Gill hyperplasia and disruption of the osmo-homeostasis mecha-

\footnotetext{
\# Correspondence: Research Institute for Fish Breeding.

Jl. Raya No. 2, Sukamandi, Subang 41256, Indonesia E-mail: yogihimawan@yahoo.com
}

nism caused by HEA intoxication interfere with hormone regulation and lead to hyperexcitability, coma, convulsions, and high HEA concentration. In intensive aquaculture, ammonia is one of the critical water quality parameters that affect fish survival (Srivastava et al. (2016),

Overcoming HEA problems in carp cultivation can be done through a genetic approach, i.e., by producing synthetic carp populations resistant to HEA. A synthetic carp is currently developed by the Research Institute for Fish Breeding (FIFB), Sukamandi, as a part of the Indonesian strategic effort to increase fish production from freshwater aquaculture. The synthetic population is assembled by blending scheme of local carp strains of Majalaya, Rajadanu, Sutisna, Wildan, and Sinyonya and then selected through the family selection method. The synthetic populations are expected to have a broad genetic diversity due to the combination of various characteristics of all 
strains used to form the population. One of the expected traits of the population is its ability to tolerate HEA concentration in a culture environment.

Some parameters that act as indicators of high ammonia resistance include the number of red blood cells, cortisol, and gene expression associated with stress response, i.e., heat shock protein $70 \mathrm{Kda}$ (HSP70). According to Fujaya (2004), the number of red blood cells is influenced by stress conditions, environmental conditions, and oxygen requirements. In stressful situations, fish will produce more red blood cells to compensate for the increased oxygen demand. In terms of hormonal activity, cortisol plays a vital role in stress response, osmoregulation, and energy metabolic processes. According to Liew et al. (2015), cortisol is a source of corticosteroids in teleost fish synthesized by the cells in the interrenal tissue of fish kidneys. Cortisol plays an essential role in improving tissue oxygenation, energy storage mobilization and homeostasis ion regulation (Hwang et al., 2011). HSP70 has a molecular weight of $70 \mathrm{Kda}$ and the level of protein stress strongly influences its level in response to non-optimal physiological conditions (Iwama et al., 1998). The increase in HSP70 gene expression in response to the HEA is affected by the rise in denatured intracellular proteins.

By observing these three indicators, the evaluation of the performance of synthetic carp populations related to high ammonia resistance could be done through a challenge test mechanism and gene expression analysis. This research is the first step in forming high ammonia-resistant carp suitable for cultured in HEAs such as lakes and reservoirs. Therefore, this study aimed to analyze synthetic carp's performance and resistance to HEA conditions.

\section{MATERIALS AND METHODS}

\section{Ammonia Challenge Test and Samples Collections}

The study was conducted in September 2018-July 2019 at the carp hatchery, research pond, and Molecular Laboratory of the Research Institute for Fish Breeding (RIFB), Sukamandi. The evaluation of tolerance to high ammonia (3 ppm) was carried out by

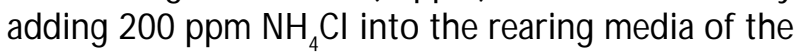
synthetic populations carp and no addition of $\mathrm{NH}_{4} \mathrm{Cl}$ as a control. Three aquariums were used for survival rate observation, and two units were used for blood and organ samplings. Each aquarium had the same size of $60 \mathrm{~cm} \times 40 \mathrm{~cm} \times 40 \mathrm{~cm}$ and was stocked with 30 carp seeds weighing 10-15 g/fish. After a four-day acclimatization period, the ammonia content in the maintenance media was increased by adding $\mathrm{NH} 4 \mathrm{Cl}$ stock solution (Merck, Darmstadt, Germany). Observations of the survival rate in the challenge test were carried out every day from the start until the end of the testing period. Calculation of the number of blood cells was done by observing the blood samples under a microscope. Blood samples were taken using a 3 $\mathrm{mL}$ syringe from the caudal vein between the fish scales near the tail. A syringe was previously moistened with a small amount of EDTA (Ethylene Diamine Tetra Acid) solution (Lavabetha et al., 2015). Observation of red blood cells used the hemocytometer method.

\section{Gene Expression}

The first step was collecting the samples for measuring the expression of synthetic carp populations treated with high ammonia. The samples used in this study were from the liver taken at the time of the challenge test with the criteria of less resistant, resistant, and control carp groups of 10 fish each, and then the organs were stored at $-80^{\circ} \mathrm{C}$ until they were ready for use for RNA extraction. Afterward, the RNA extraction from the liver was collected, taken as much as $20 \mathrm{mg}$ from each test and then isolated using Trizol (Invitrogen, Merelbeke, Belgium). The next stage was for quantitative PCR (qPCR) reactions of HSP70 and Beta-actin genes related to stress resistance due to high ammonia stress using primers (Sinha et al., 2012) as listed in Table 1.

Quantifying the relative expression of the target gene transcript with the reference gene was carried out using the Rotor-Gene Q Series Software method. Significant differences in expressions between control and treatment were analyzed using Rotor-Gene Q 2.3.1 Real-Time Data Acquisition and Analysis Software. Research data were analyzed using Analysis of variance (ANOVA) at a $5 \%$ level of significance.

\section{RESULTS AND DISCUSSION}

In general, the survival rate of the synthetic carp populations in the high ammonia challenge test decreased gradually within 12 hours (Figure 1).

The synthetic carp survival rate in aquarium 1 decreased to $63.33 \%$ at the $2^{\text {nd }}$ hour $(09.00)$. Further observation at the $12^{\text {th }}$ hour (at 19.00) showed that the survival rate of fish in aquarium 1 was only $6.67 \%$ However, all survived fish exhibited a strong appearance despite exposure to the high ammonia concentration. In aquariums 2 and 3, the survival rates of fish were $13.33 \%$ and $0.00 \%$ respectively. All fish that survived after 12 hours of the test period were grouped into three groups named according to their performance: control, less resistant, and resistant synthetic carps. 
Table 1. The primer used in qPCR of HSP70 gene.

\begin{tabular}{|c|c|}
\hline Genes & Primary sequence $\left(5^{\prime} \rightarrow 3^{\prime}\right)$ \\
\hline \multirow[t]{2}{*}{ HSP70 } & F: 5'-GGCAGAAAGTTTGATGACCCA-3' \\
\hline & R: 5'-GCAATCTCCTTCATCTTCACC-3' \\
\hline \multirow[t]{2}{*}{ Beta Actin } & F : 5'-CCCTGGCCCCCAGCACAATG-3' \\
\hline & R : 5'-TCTGCGCAGTTGAGTCGGCG-3' \\
\hline
\end{tabular}

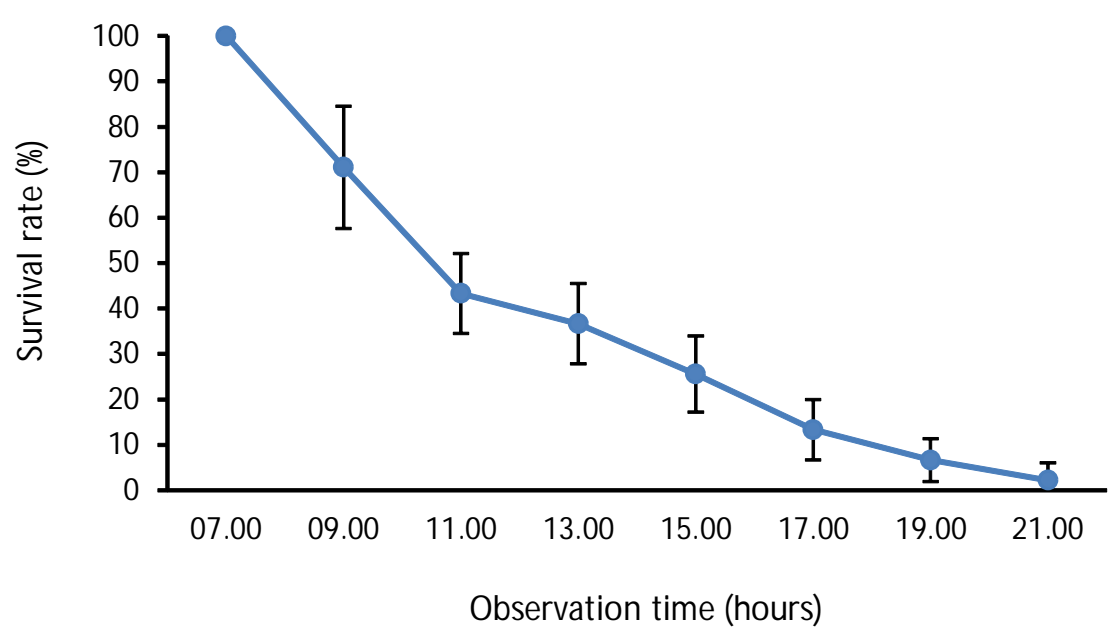

Figure 1. The survival rate of synthetic fish in the high ammonia challenge test.

Ammonia resistant fish usually make a compensation strategy by converting ammonia accumulation to glutamine and other amino acids, reducing ammonia production by decreasing acid catabolism, ammonia detoxification to urea, and augmentation excretion concentration by the gradient (Shrivastava et al., 2016). In addition, fish also have other strategies in dealing with ammonia toxicity at the cellular and subcellular levels. Douxfils et al. (2012) reported that stressed Eurasian perch fish (Perca fluviatilis) activated the formation of physiological defenses and immune responses. Ammonia testing in Koki Carrasius auratus, one of the ammonia-resistant carp species, showed that the posterior side of the lamella was suspected of having a role in regulating cell mass capacity to inhibit ammonia excretion (Perry et al., 2016b).

The number of red blood cells in the synthetic fish populations in the high ammonia test differed between the control, less resistant, and resistant fish (Figure 2).

Fish in the control group had an average red blood cell number of $78.66 \pm 3.05$ cells $/ \mathrm{mL}$, while those in the less resistant and resistant groups had average red blood cell counts of $79.33 \pm 23.09$ cells $/ \mathrm{mL}$ and $232.66 \pm 17.24$ cells $/ \mathrm{mL}$, respectively. The ANOVA re- sults confirmed an effect of high ammonia on the red blood cell count $(p<0.05)$. The stress conditions caused by high ammonia levels affected the number and character of carp red blood cells. The stressed carp responded to high ammonia by releasing more red blood cells, accelerating blood cell maturation, and producing new red blood cells or called erythropoiesis. Under stress conditions, carp adapt by producing immature and mature red blood cells, which are different from normal conditions. A spleen can release red blood cells in the blood circulation when tissue requires high oxygen. Research on other cyprinid fish revealed that their spleens increased the amount of red blood cell circulation significantly (Yamamoto, 1983), while the spleens of rainbow trout released $95 \%$ of its red blood cell deposits at the time of anoxia. The spleen of carp contributes to the release of $15 \%$ of immature red blood cells after 4 hours in waterless conditions (Chen et al., 2014). The other responses of carp to stress conditions are hyperventilation, increased perfusion, increased gas exchange in the gills, and the release of red blood cells in the spleen.

Under stressful conditions, carp can develop an adaptation system that can regenerate red blood cells quickly by $35 \%$ within 20 hours and continues for up 


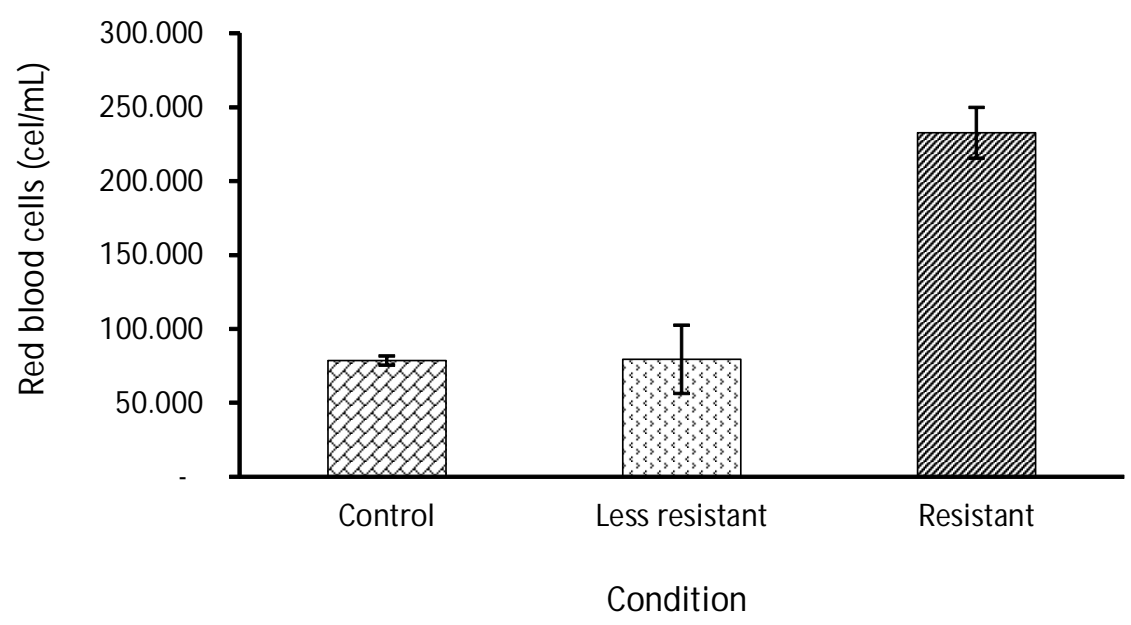

Figure 2. The number of red blood cells in challenging test of high ammonia.

to 92 hours. Of the $35 \% 15 \%$ of red blood cells are released by the spleen, while $20 \%$ are produced from erythropoiesis. Thus, the ability of carp to rapidly regenerate red blood cells under stress conditions is one of the critical mechanisms of adaptation to environmental stress.

The carp cortisol levels in the synthetic populations during the high ammonia challenge test showed different values in control, less resistant, and resistant groups (Figure 3).

The cortisol hormone in the synthetic carp populations during the high ammonia challenge test showed that carp in the control group reached an average value of $66.52 \pm 7.83 \mathrm{ng} / \mathrm{mL}$. In contrast, less resistant and resistant groups reached average values of $73.81 \pm 11.55 \mathrm{ng} / \mathrm{mL}$ and $80.90 \pm 6.35 \mathrm{ng} / \mathrm{mL}$, respectively. Analysis of synthetic carp cortisol levels during the high ammonia challenge test showed dif- ferences $(p<0.05)$ in control, less resistant, and resistant groups.

Cortisol in teleost fish is produced and released from the kidneys as a neuroendocrine stress response (Tort, 2011). According to McCormick (2012), cortisol induces an increase in the surface of the mitochondria that has many cells and affects the branchial and renal function of freshwater fish, which influences the entry of $\mathrm{Na}^{+}$and $\mathrm{Cl}$. Along with the increase in cortisol, hyper cortisol induces liver protein mobilization for gluconeogenesis and increases lactic acid levels as an indication of anaerobic metabolism. According to Liew et al. (2013a), cortisol affects aerobic and anaerobic metabolisms simultaneously by increasing plasma lactate and ammonia excretion in carp. Hyperglycemia is also reported to occur in carp in response to increased plasma cortisol (Liew et al., 2013b). Overall, cortisol affects the shift in metabo-

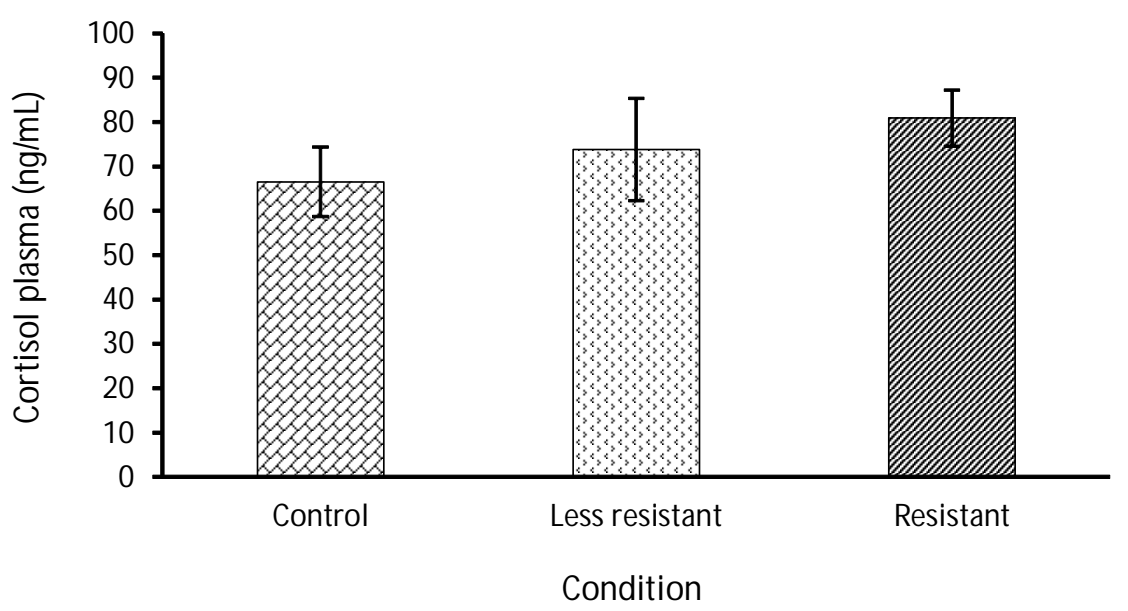

Figure 3. Cortisol levels in synthetic carp populations during high ammonia challenge test. 
lism by increasing liver protein and liver and muscle glycogenesis. In addition, high cortisol levels modulate ion regulation in the gills and affect the regulation of kidney ions by inducing active $\mathrm{H}^{+}$ATP activity. In this case, cortisol serves to encourage gluconeogenesis and mobilize glucose to trigger gill metabolism, including hypo-osmoregulation activity (McGuire et al., 2010).

According to Williams et al. (2017), high environmental ammonia (HEA) exposure in zebrafish larvae can stimulate the hypothalamic-pituitary interrenal (HPI) axis. HEA also has a persistent effect on the neuroendocrine response to a stressor. However, it remains to be proven whether the stress response of cortisol affects the nervous system's sensitivity to stress. The zebrafish were still able to be significantly improved post the ammonia test exposure. Carp (Cyprinus carpio) exposed to high ammonia also had a higher survival rate post ammonia exposure (Shrivastava et al., 2016). Cortisol causes glycogenolysis in the liver, producing glucose to be used by skeletal muscles. Cortisol can also reduce the gluconeogenic system to maintain glucose availability in the tissues and affect free fatty acids and blood protein concentrations (Sadoul \& Vijayan, 2016). Cortisol also plays a major role in restoring osmotic and ionic balance after a stress period caused by hydromineral imbalances (Takei \& Hwang, 2016).

The observation of HSP70 gene expression using Real-Time Polymerase Chain Reaction (RTPCR) showed that carp had different responses to high ammonia stress, which were indicated by different values of relative expression genes in each group of carp (Figure 4).

qPCR results using the Rotor-Gene machine showed a higher relative expression ratio value of the resistant group compared to the less resistant group. This result indicates that the HSP70 gene plays a role in supporting the ability of carp to adapt through a mechanism to prevent protein damage due to stress caused by high ammonia.

Aquatic organisms, especially fish species, encounter a variety of stresses during their continuous interaction with the environment from the very early stages of their life (Amaeze et al., 2015). Poor environmental conditions can also impair fish health, growth, fitness (Sueiro \& Palacios, 2016).

The HSP70 gene is one of the genes responsible for providing defense mechanisms against stress at a cellular level. In addition, the gene also plays a vital role in regulating proteins in response to stress due to suboptimal physiological conditions. Therefore, HSP70 can be a valuable biomarker for assessing stress in fish (Tedeschi et al., 2015).

The expression of HSP70 will increase during highstress level conditions due to increased damage and denaturation of intracellular proteins. High ammonia is known to have a detrimental effect on cell proteins and amino acid homeostasis, leading to increased protein fragments resulting in proteotoxicity. The expression of an induced form of HSP70 genes in response to stress has been observed in many fish species like Haliotis discus, Caretta caretta, Garra rufa, Clarias batrachus, Sparus aurata, and Chromis viridis (Oksala et al. 2014). Similar results were observed on brown trout (Salmo trutta f fario) when exposed to the sublethal ammonia concentration. HSP70 is a protein chaperone with many cellular functions, including folding nascent proteins, refolding misfolded proteins, and helping protein transport between cellular compartments.

When fish are in stress conditions, the endogenous tissue protein will be broken down to supply

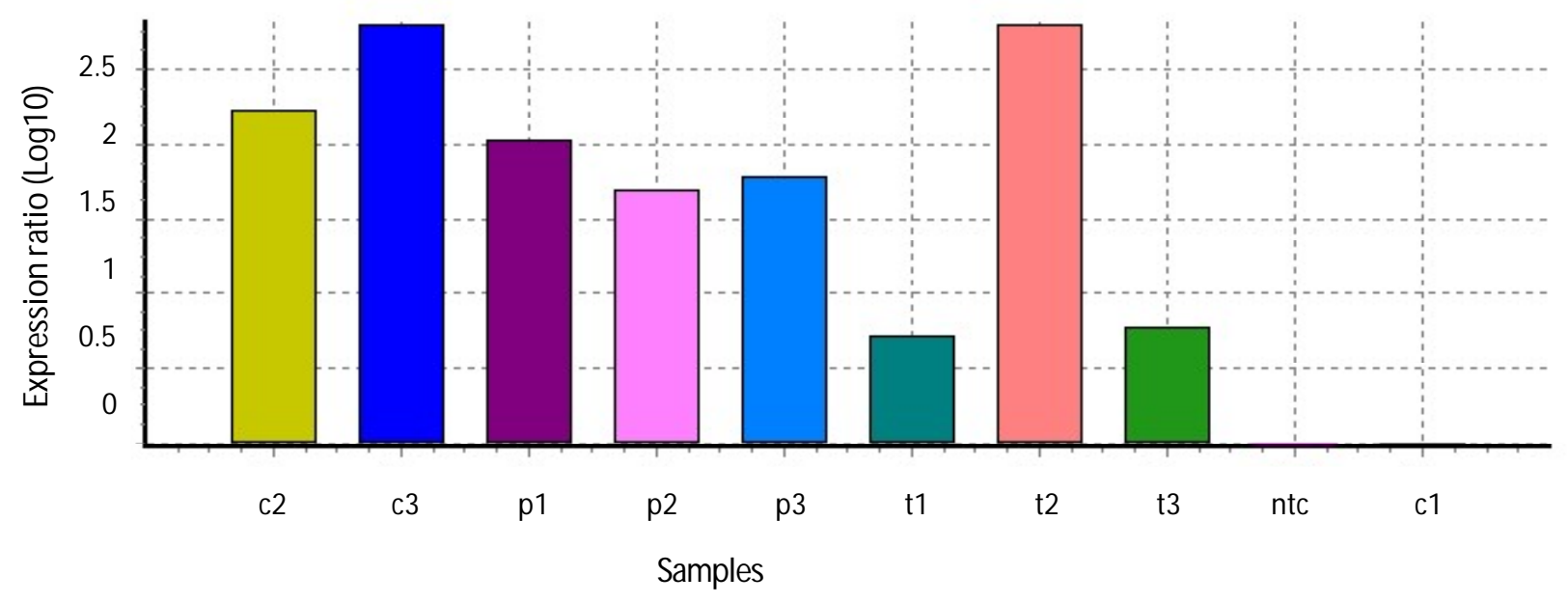

Figure 4. Relative expressions of the HSP70 gene using RTPCR method. 
the required amino acids leading to tissue breakdown, thus affecting cellular protein homeostasis. The results of this study suggest that HSP70 is expressed as a protective strategy against stress in common carp. Correspondingly, Cara et al. (2005) also demonstrated that food deprivation enhanced HSP70 and HSP90 expression in gilthead sea bream (Sparus aurata) and rainbow trout (Oncorhynchus mykiss) larvae. Similarly, the liver of Labeo rohita fingerlings was highly sensitive to feed deprivation which is evident from the increase in HSP70 induction corresponding to the increase in the duration of starvation (Yengkokpam et al., 2008). This study argues that the expression of HSP70 as an indicator of stress and animal health status holds a promising application in ecotoxicological studies. Stress conditions can have immediate effects on fish, such as energy depletion, oxygen deprivation, generation of reactive oxygen species, and lactate production, leading to cellular damage. In the high environmental ammonia challenge test, HSP70 served as a protective mechanism against subsequent potential damage to the tissues of tested fish.

\section{CONCLUSIONS}

The populations of synthetic F2 carp showed resistance against high ammonia conditions by inducing high red blood cells ( $232.66 \pm 17.24$ cells $/ \mathrm{mL})$, high cortisol level $(80.90 \pm 6.35 \mathrm{ng} / \mathrm{mL})$, and HSP70 gene expression in the liver with relative expression values of $0.72-2.80$. When it is ready for aquaculture, this synthetic carp strain could be farmed in high density using an intensive system in artificial lakes where high ammonia frequently occurs.

\section{ACKNOWLEDGEMENT}

The authors gratefully acknowledge the funding support of PUSDIK KP. The authors also thank the Research Institute for Fish Breeding (RIFB) Sukamandi for providing support during the field research.

\section{REFERENCES}

Cara, J.B., Aluru, N., Moyano, F.J., \& Vijayan, M.M. (2005). Food deprivation induces HSP 70 and HSP 90 protein expression in larval and gilthead sea bream and rainbow trout. Comparative Biochemistry and Physiology. Part B, Biochemistry \& Molecular Biology, 142, 426-431.

Chen, Y.H., Chen, H.H., \& Jeng, S.S. (2014). Rapid renewal of red blood cells in the common carp following prolonged exposure to air. Fisheries Science, 81(2), 255-265.
Douxfils, J., Deprez, M., Mandiki, S.N.M., Millam S., Henrotte, E., Mathieu, C., Silvestre, F., ..... \& Dieu, M. (2012). Physiological and proteomic responses to single and repeated hypoxia in juvenile Eurasian perch under domestication clues to physiological acclimation and humoral immune modulations. Fish Shellfish Immunol, 33, 11121122.

Fujaya, Y. (2004). Fisiologi Ikan: Dasar Pengembangan Teknik Perikanan. Rineka Cipta, Jakarta, 179 pp.

Hegazi, M.M. \& Hasanein, S.S. (2010). Effects of chronic exposure to ammonia concentrations on brain monoamines and ATPases of Nile tilapia (Oreochromis niloticus). Comparative Biochemistry and Physiology Part C. Toxicology \& Pharmacology, 151, 420-425.

Hwang, P.P., Lee, T.H., \& Lin, L.Y. (2011). Ion regulation in fish gills: recent progress in the cellular and molecular mechanisms. Am.J.Physiol.Regul.Integr. Comp.Physiol, 301, 2847.

Iwama, G. \& Nakanishi T. (1996). The Fish Immune System. Academic Press, London, 380 pp.

Kawasaki, N., Kushairi, M.R.M., Norio, N., Fatimah, Y., Akio, I., \& Ayato, K. (2016). Release of Nitrogen and phosphorus from aquaculture farms to Selangor River, Malaysia. International Journal of Environmental Science and Development, 7, 113116.

Lavabetha, A.R.R.R., Hidayaturrahmah, M., \& Heri, B.S. (2015). Blood profile of Timpakul (Periophthalmodon schlosseri) from Barito river estuary of South Kalimantan. Bioscientiae, 12, 7889.

Liew, H.J., Chiarella, D., Pelle, A., Fagio, C., Blust, R., De Boeck, G. (2013b). Cortisol emphasizes the metabolic strategies employed by common carp, Cyprinus carpio at different feeding and swimming regimes. Comp. Biochem. Physiol. A Mol. Integr. Physiol, 166, 449-464.

Liew, H.J., Fazio, A., Faggio, C., Blust, R., \& De Boeck, G. (2015). Cortisol affects metabolic and ion regulatory responses to a different extent depending on feeding ration in common carp, Cyprinus carpio. Comparative Biochemistry and Physiology Part A: Molecular and Integrative Physiology, 189, 45-57.

Liew, H.J., Sinha, A.K., Mauro, N., Diricx, M., Darras, V.M., Blust, R., \& de Boeck, G. (2013a). Feeding and swimming modulate iono-and-hormonal regulation differently in goldfish, Carrasius auratus and 
common carp, Cyprinus carpio. Comp. Biochem. Physiol. A Mol. Integr. Physiol, 165, 13-21.

McCormic, S.D. (2012). The hormonal control of osmoregulation in teleost fish. In: Farrel AD (Ed), from genome to environmental. Encyclopedia of Fish Physiology Vol 2. Academic Press. San Diego, p. 1466-1473.

McGuire, A., Aluru, N., Akihiro, T., Weil, R., Wilson, J.M., \& Vijayan, M.M. (2010). Hyperosmotic shock adaptation by cortisol involves upregulation of branchial osmotic tress transcription factor 1 gene expression in Mozambique tilapia. Gen. Comp. Endocrinol, 165, 321-329.

Oksala, N.K.J., GülerEkmekçi, F., Ozsoy, G., Kirankaya, S., Kokkola, T., Emecen, G., Lappalainen, J., Kaarniranta, K., \& Atalay, M. (2014). Natural thermal adaptation increases heat shock protein levels and decreases oxidative stress. Redox Biology, 3, 25-28.

Perry, S.F., Schwaiger, T., Kumai, Y., Tzaneva, B., \& Braun, M.H. (2016b). The Consequences of reversible gill remodeling on ammonia excretion in goldfish (Carrasius auratus). J. Exp. Biol, 213, 36563665.

Sadoul, B. \& Vijayan, M.M. (2016). Stress and growth. In fish Physiology-Biology of Stress in Fish. Vol 35 (eds Shreck CB, Tort, Farrell AP, Brauner CJ). San Diego CA. Academic Press, p. 167-205.

Shrivastava, J., Sinha, A.K., Datta, S.N., Blust, R., \& De Boeck, G. (2016). Pre acclimation to low ammonia improves ammonia handling in common carp (Cyprinus carpio) when exposed subsequent to high environmental ammonia. Aquatic Toxicology, 180, 334-344.

Sinha, A.K., Matev, V., Giblen, T., Blust, R., \& De Broeck, G. (2014). Gill remodeling in three fresh- water teleosts in response to high environmental ammonia. Aquat. Toxicol, 155, 166-180.

Sueiro, S.C. \& Palacios, M.G. (2016). Immunological and health-state parameters in the Patagonian rockfish Sebastes Oculatus. Their relation to chemical stressors and seasonal changes. Fish \& Shellfish Immunology, 48, 71-78.

Takei, Y. \& Hwang, P.P. (2016). Homeostatic Responses to Osmotic Stress. In fish Physiology-Biology of Stress in Fish. Vol 35 (eds Shreck CB, Tort, Farrell AP, Brauner CJ). San Diego CA. Academic Press, p. 207-249.

Tedeschi, J.N., Kennington, W.J., Berry, O., Whiting, S., Meekan, M., \& Mitchell, NJ. (2015). Increased expression of Hsp70 and Hsp90 mRNA as biomarkers of thermal stress in loggerhead turtle embryos (Caretta Caretta). Journal of Thermal Biology, 47, 42-50.

Tort, L. (2011). Stress and immune modulation in fish. Dev. Comp. Immunol, 35, 1366-1375.

William, T.A., Bonham, L.A., \& Bernier, N.J. (2017). High environmental ammonia exposure has developmental stage-specific and long term consequences on the cortisol stress response in zebrafish. General and Comparative Endocrinology, 254, 97-106.

Yamamoto, K., Itazawa, Y., \& Kobayashi, H. (1983). Erythrocyte supply from the spleen and hemoconcentration in hypoxic yellowtail. Mar Biol., 73, 221-226.

Yengkokpam, S., Pal, A.K., Sahu, N.P., Jain, K.K., Dalvi, R., Misra, S., \& Debnath, D. (2008). Metabolic modulation in Labeo rohita fingerlings during starvation: Hsp70 expression and oxygen consumption. Aquaculture, 285, 234-237. 